The Influence of Climate on Phytoplankton Community Biomass in San Francisco Bay Estuary Author(s): P. W. Lehman

Source: Limnology and Oceanography, Vol. 45, No. 3 (May, 2000), pp. 580-590

Published by: American Society of Limnology and Oceanography

Stable URL: http://www.jstor.org/stable/2670835

Accessed: 21/09/2010 18:57

Your use of the JSTOR archive indicates your acceptance of JSTOR's Terms and Conditions of Use, available at http://www.jstor.org/page/info/about/policies/terms.jsp. JSTOR's Terms and Conditions of Use provides, in part, that unless you have obtained prior permission, you may not download an entire issue of a journal or multiple copies of articles, and you may use content in the JSTOR archive only for your personal, non-commercial use.

Please contact the publisher regarding any further use of this work. Publisher contact information may be obtained at http://www.jstor.org/action/showPublisher?publisherCode=limnoc.

Each copy of any part of a JSTOR transmission must contain the same copyright notice that appears on the screen or printed page of such transmission.

JSTOR is a not-for-profit service that helps scholars, researchers, and students discover, use, and build upon a wide range of content in a trusted digital archive. We use information technology and tools to increase productivity and facilitate new forms of scholarship. For more information about JSTOR, please contact support@jstor.org. 


\title{
The influence of climate on phytoplankton community biomass in San Francisco Bay Estuary
}

\section{P. W. Lehman 1}

Department of Water Resources, 3251 S Street, Sacramento, California 95816

\begin{abstract}
The distribution of biomass within the phytoplankton community in northern San Francisco Bay Estuary was influenced by environmental conditions resulting from an interdecadal climate regime shift between 1975 and 1993 . A decrease in percentage of diatom biovolume characterized the period 1975-1989 and was caused by both a decrease in diatom and an increase in green and bluegreen algae and flagellate species biovolume. Among the diatoms, there was a greater loss of pennate than centric diatoms. The direct role of climate variation on phytoplankton community biovolume was determined using climatically-related environmental variation that was isolated from the total environmental variation using the covariance between a California climate index and a suite of physical and chemical variables and summarized by principal component analysis. Significant correlation between climatically-related environmental variation and phytoplankton species and species group biovolume suggested a link between climate and the distribution of biovolume in the phytoplankton community. Further analysis of the possible mechanisms controlling the association between climatically-related environmental variation and phytoplankton community biovolume confirmed the importance of water temperature, specific conductance, and water transparency to pennate diatom biovolume. Comparison of natural and anthropogenic processes indicated that diatom biovolume at each station was influenced by environmental conditions even though total diatom biovolume in the estuary was strongly influenced by water diversion.
\end{abstract}

Climate is a strong driving force in the eastern Pacific, where its effect on precipitation regulates interannual streamflow in northern San Francisco Bay Estuary (SFBE) (Peterson et al. 1989). Climate also controls interdecadal changes in SFBE streamflow, including the increased frequency and intensity of wet and critically-dry water-year types produced by the 1977 climate regime shift in the eastern Pacific (Trenberth and Hurrell 1994). The coincident decrease in diatom density and chlorophyll $a$ (Chl $a$ ) concentration and increase in flagellate density with changes in environmental factors controlled by climate after 1976 (Lehman and Smith 1991; Lehman 1992; 1996a), suggested climate was also a controlling factor for phytoplankton biomass and community composition in northern SFBE. This was supported by the variation of $\mathrm{Chl} a$ concentration and species composition with water-year type, which is a direct function of climate (Lehman 1996a). However, there is no information on how climate may affect the distribution of biomass in the phytoplankton community, which may be important to the quantity and quality of carbon available at the base of the food web.

Previous research suggests climate could influence phytoplankton $\mathrm{Chl} a$ concentration and species composition in northern SFBE through direct and indirect factors associated with streamflow. Streamflow directly affects upstream and downstream transport of Chl $a$ biomass (Lehman 1992; Jass-

' Corresponding author (plehman@water.ca.gov).

\section{Acknowledgments}

This project was funded by the Interagency Ecological Program. Many thanks to the members of the Pacific Climate Workshop (PACLIM) for helpful comments and suggestions, particularly D. Cayan for providing the climate index data. The views in this paper do not necessarily reflect the views of the Department of Water Resources. by et al. 1996) and phytoplankton species composition (Cloern and Cheng 1981; Lehman and Smith 1991) and both density and Chl $a$ biomass vary directly with precipitation patterns (Peterson et al. 1989; Lehman 1996a). Streamflow also indirectly affects the physical, chemical, and biological factors that control growth and biomass accumulation, including nutrient concentration and turbidity (Peterson et al. 1989; Jassby et al. 1996) and the abundance of pelagic benthic grazers (Nichols 1985). Streamflow is similarly important in the Chesapeake, St. Lawrence, and Columbia River Estuaries, where it regulates Chl $a$ concentration (Therriault and Levasseur 1985; Malone et al. 1988; Sherwood et al. 1990) and species composition, (Tyler and Seliger 1981; Frenette et al. 1995) through controls on transport processes and limiting factors such as nutrient concentration (Conley and Malone 1992) and light (Therriault and Levasseur 1985).

The potential influence of climate on environmental conditions that control phytoplankton species composition has long been recognized for aquatic ecosystems (Hutchinson 1967) and has often been associated with interannual and interdecadal changes in phytoplankton community composition in a variety of aquatic habitats. Off the California coast, warm-water diatoms were more abundant than coolwater diatoms in sediment varves (Baughmgartner et al. 1985) and dinoflagellates were more abundant than diatoms in planktonic communities (Tont 1989) with the reduced upwelling and increased sea level and water temperature during El Niño years. In addition, diatom density in the Santa Barbara Basin decreased by a factor of 2 after the 1977 climate regime shift in the eastern Pacific (Lange et al. 1990). Off the Peruvian coast, a shift from diatoms to flagellates was also associated with the suppression of upwelling in El Niño years (Barber and Chavez 1983). In the North Sea, phytoplankton total density (Colebrook 1986) and species composition (Dickson and Reid 1983) varied with local weather 


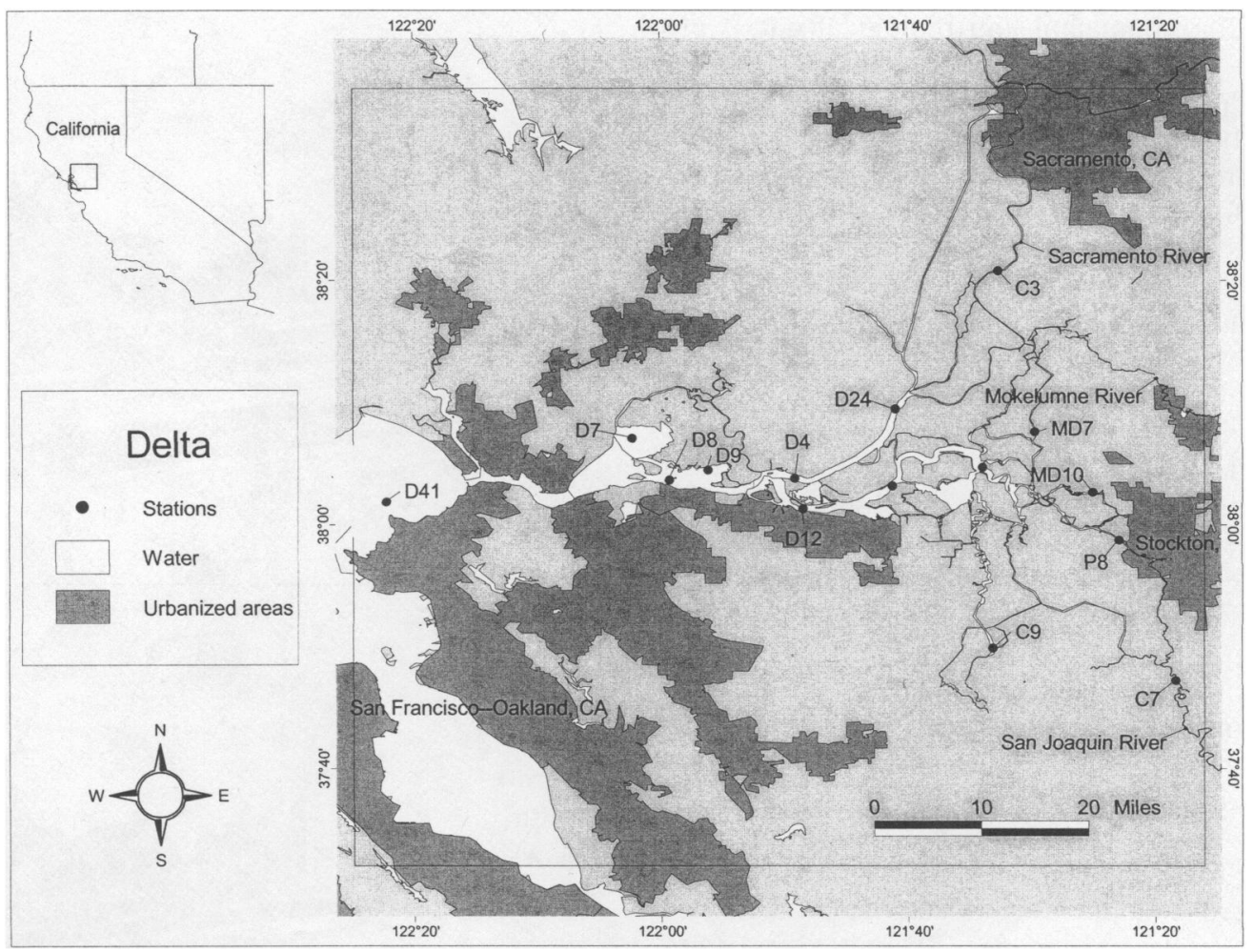

Fig. 1. Map of northern San Francisco Bay Estuary showing sampling stations.

conditions and total density decreased by a factor of 2 after the 1977 climate shift (Aebischer et al. 1990). In lakes, climate controls phytoplankton community composition by the influence of inflow on water quality variables (Kilham et al. 1996), the release of nutrients at turnover (Strub et al. 1985), timing of the spring thaw, outwash rate, and depth of spring mixing (Goldman et al. 1989). In estuaries, seasonal changes in species composition are influenced by hydrologic inputs of nutrients (Mallin 1994).

The purpose of this study was to determine if climaterelated changes in environmental conditions contributed to the change in the distribution of biovolume within the phytoplankton community in SFBE between 1975 and 1993. This information can provide valuable information on the influence of global climate-change on phytoplankton community composition and biomass and insight into their potential influence on estuarine production. A change in the distribution of biomass within the phytoplankton community can affect the quality and quantity of carbon available at the base of the food web (Muller and Lampert 1996) and may have contributed to recent declines in fishery resources in SFBE (Bennett and Moyle 1996).

\section{Methods}

Sample collection-Environmental and biological variables were measured monthly or semi-monthly at 15 stations (Fig. 1) during the spring and summer (April-September) between 1975 and 1993 by the California Department of Water Resources and U.S. Bureau of Reclamation. Physical and chemical measurements included streamflow, water di- version, Secchi disk depth, wind velocity, air and water temperature, $\mathrm{pH}$, and specific conductance. Water samples for determination of turbidity, volatile suspended solids, total suspended solids, total dissolved solids, dissolved oxygen concentration, and nutrient concentration, including nitrate plus nitrite, ammonia plus organic nitrogen, silica, orthophosphate, total phosphate, and dissolved organic nitrogen, were collected at 1-m depth and frozen or kept cool until analysis (US EPA 1983). Nutrient ratios were calculated as silica to orthophosphate $(\mathrm{Si}: \mathrm{P})$, silica to nitrate plus nitrite $(\mathrm{Si}: \mathrm{N})$, and nitrate to orthophosphate (N/P).

Water samples for phytoplankton species enumeration and identification were also collected at 1-m depth and immediately preserved in Lugol's solution. Phytoplankton species were identified at $\times 700$ using the inverted microscope technique and aggregated into the following groups: diatom, green algae, chrysophyte, cryptophyte, bluegreen algae, dinoflagellate, green flagellate, and miscellaneous flagellate. Phytoplankton species count data were converted to cell volume $\left(\mu \mathrm{m}^{3}\right)$ using cell dimensions applied to regular geometric shapes. By adjusting cell volume to account for the large vacuole in diatoms, the volume data became a surrogate for phytoplankton carbon biomass (Strathmann 1967). Biovolume, rather than density, was the preferred phytoplankton variable for this study because it allowed an evaluation of the potential influence of climate on carbon availability, which has a direct effect on estuarine production. Further, details of the analytical methods for physical, chemical, and biological variables and a further description of phytoplankton groups are described in Lehman $(1996 a, b)$. 
Data analysis-Environmental and biological data were stratified by water-year type. Water years since 1906 in SFBE have been classified as wet, above normal, below normal, dry or critically-dry (critical) water-year types based on the Sacramento Four Rivers index, which is an estimate of the combined unimpaired runoff of four rivers that feed into the estuary (CDWR 1998). However, both above and below normal water-year categories for this study were coded as normal years, because only three years were in these two water-year types between 1975 and 1993.

Stratification of the data by water-year type was a useful tool for evaluating the influence of climate change associated with El Niño on the estuary, because El Niño produces a bimodal signal in the SFBE region. As a result of this bimodal response, a strong El Niño in SFBE will produce either a wet year like 1982 or a critically-dry year like 1977. In addition, stratification of the data by water-year type allowed extrapolation of the 1975-1993 environmental and biological data associations to the rest of the century through hydrology. The climate signal associated with each wateryear type was described by the CASLP monthly climate index that is derived from sea level pressure at $40^{\circ} \mathrm{N}$ and $120^{\circ} \mathrm{W}$ and is particularly good at separating wet and very dry conditions in SFBE (Peterson et al. 1989).

All analyses were conducted with seasonally corrected standardized data. Standardized values (SD units) were computed for each station and variable as the monthly average minus the average for that month over all years divided by the standard deviation for that month over all years. As a result of this standardization, zero values describe the mean, while positive values are higher than average and negative values are lower than average. Monthly standardized values were averaged by station over water-year type for water-year type comparisons, principal component analysis (PCA), and correlation analysis. Differences among environmental and biological variables among water-year types were determined using the Kruskal-Wallis test in combination with a multiple range test. The robust and conservative nature of this nonparametric statistical approach focused the analysis on major differences in the data.

Climatically related environmental variation among wateryear types was calculated as the covariance between seasonally corrected monthly values of the climate index and environmental variables at each station stratified by water-year type. This climatically-related environmental variation among water-year types was summarized by PCA of noncorrelated $(r<0.70)$ variables. PCA allowed an objective characterization of environmental conditions associated with water-year types, including any unknown interactions among variables that analysis of individual variables precludes. Correlation between principal component axes scores and phytoplankton species or species group biovolume was computed with Pearson correlation coefficients.

\section{Results}

Phytoplankton community density and biovolume-Percentage of diatom density (cells $\mathrm{L}^{-1}$ ) decreased between 1975 and 1989 by $60 \%$ and was accompanied by increased
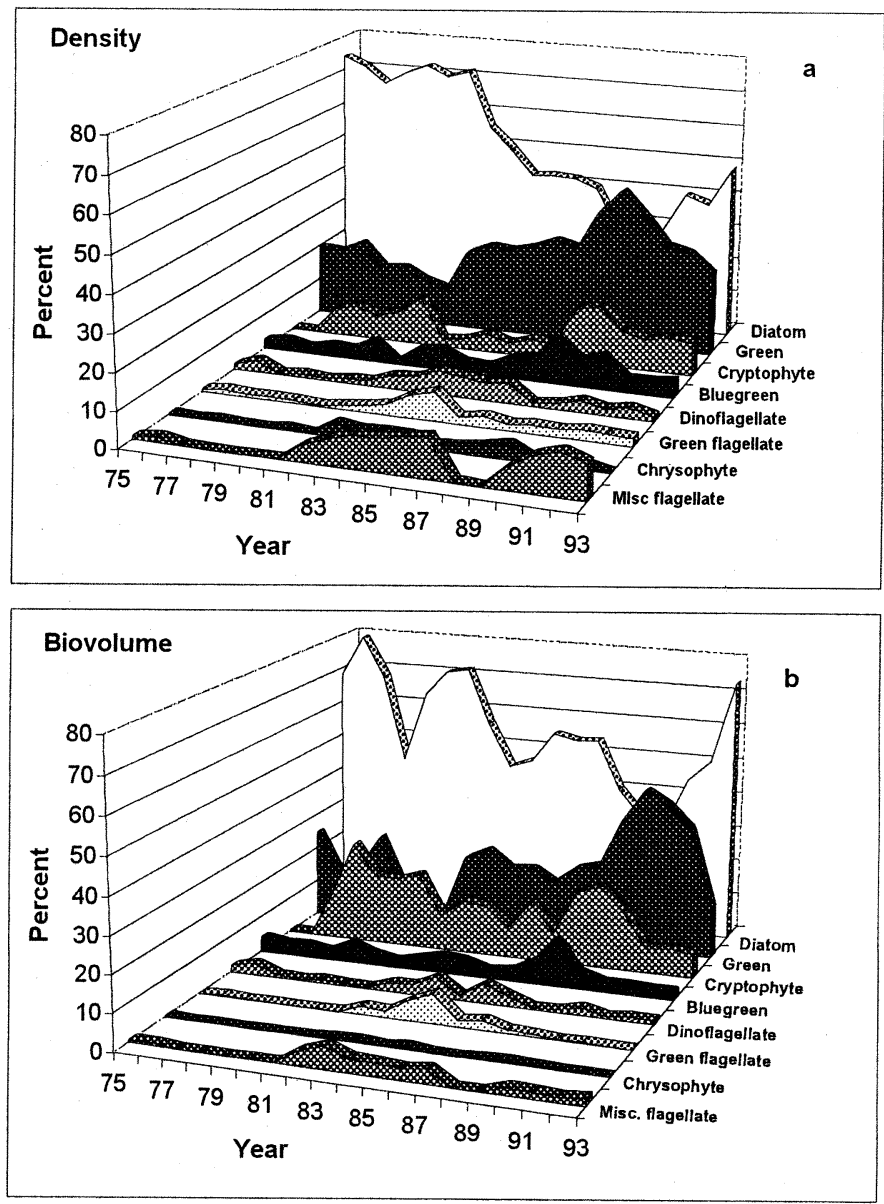

Fig. 2. Yearly average percent (a) density, and (b) biovolume among phytoplankton species groups.

percent density of green algae, bluegreen algae, and flagellates - chrysophyte, cryptophyte, dinoflagellate, green flagellate, and miscellaneous flagellate (Fig. 2a). The decrease in diatom and increase in green, bluegreen, and flagellate group density represented a change in the distribution of phytoplankton biovolume within the phytoplankton community, because both density and biovolume varied in a similar fashion (compare Fig. 2a,b). The preceding graphs describe average annual changes in percent density and biovolume at all stations, but were representative of those that occurred in nine separate regions throughout the northern estuary (not shown).

Both a decrease in diatom biovolume and an increase in nondiatom biovolume (Fig. 3) caused the decrease in percentage of diatom biovolume $\left(\mu \mathrm{m}^{3} \mathrm{~L}^{-1}\right)$ in the 1980s. Lowerthan-average diatom biovolume after 1982 was accompanied by higher-than-average biovolume of green and bluegreen algae and flagellate groups-cryptophytes, miscellaneous flagellates, dinoflagellates, and green flagellates. The apparent recovery in percentage of diatom biovolume in the 1990s (Fig. 2b) was not a return to conditions in the early 1970s, because diatom biovolume remained below average (Fig. 3).

Among the diatoms, there was a greater loss of pennate than centric diatom biovolume. Pennate biovolume was usu- 

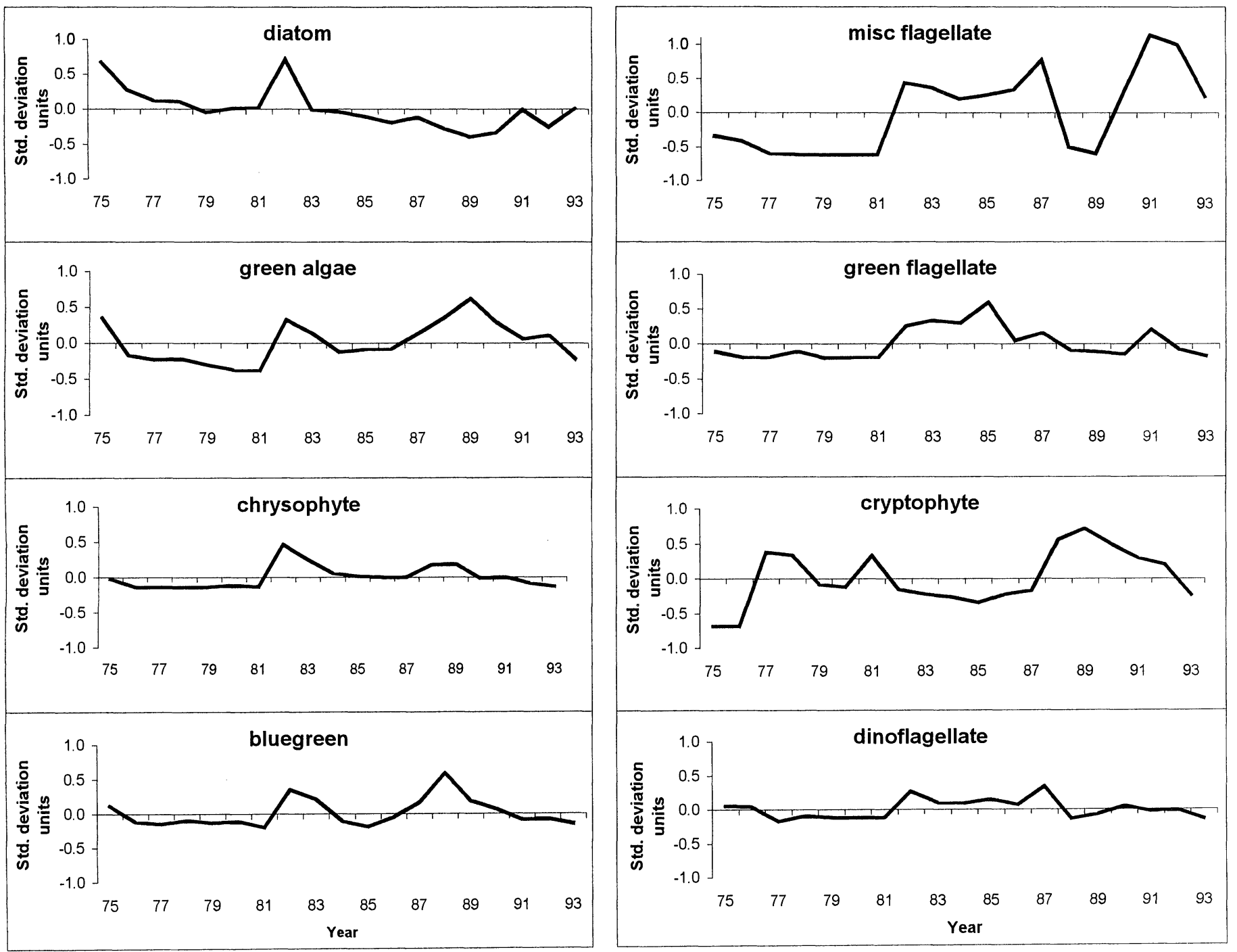

Fig. 3. Yearly average SD units for phytoplankton species group biovolume.

ally at or above average between 1975 and 1982, but was often lower-than-average thereafter (Fig. 4). In contrast, centric diatom biovolume waxed and waned around the average throughout the 19-year record. Pennate diatom biovolume

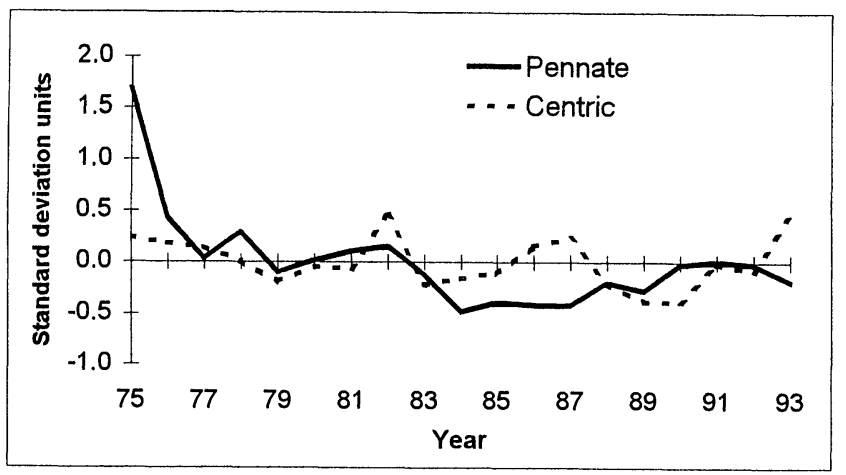

Fig. 4. Yearly average SD units for centric and pennate diatom biovolume. closely matched the decrease in total diatom biovolume, but comprised only $5-35 \%$ of the average diatom biovolume compared with $65-95 \%$ for centric diatoms.

Climatic variation-Inflows among water-year types described unusual conditions between 1975 and 1993 compared with the rest of the century. The 1975-1993 period was either wet or critically-dry with few normal and dry years (Fig. 5) and contrasted with previous 19-year periods when normal and dry years were abundant. Critically-dry water years occurred 7 times between 1975 and 1993, but 6 or less times in the three previous 19-year periods. This change in hydrology probably reflected the increased frequency and intensity of El Niño phenomena associated with the 1977 climate regime shift in the eastern Pacific (Trenberth and Hurrell 1994).

The significantly different physical and chemical conditions associated with each water-year type confirmed the ecological importance of these categories. Critically-dry years had higher-than-average air and water temperature, 


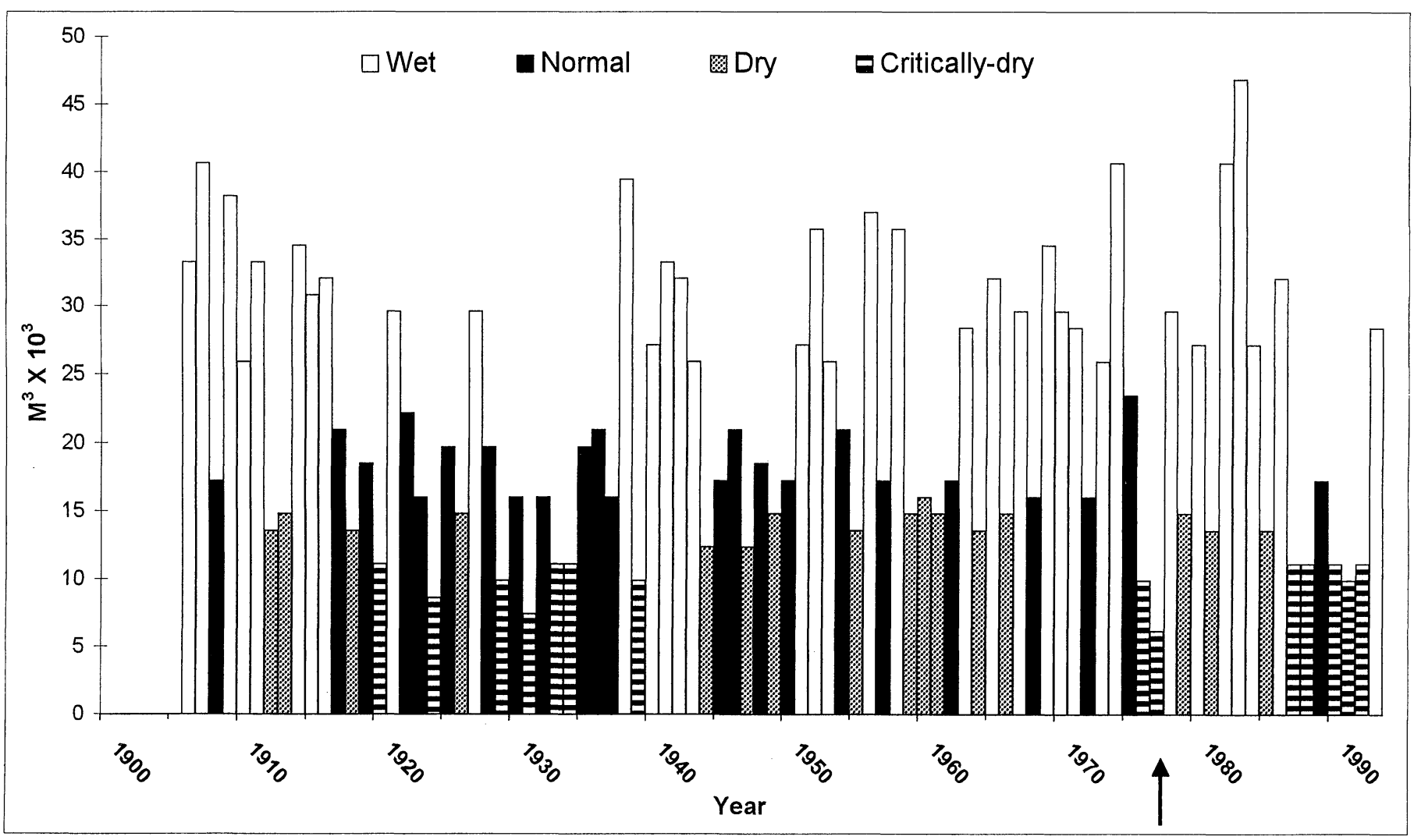

Fig. 5. Yearly average unimpaired inflows to the Sacramento River basin, 1906-1993. The arrow indicates the climate shift in 1977.

wind velocity, specific conductance, $\mathrm{pH}$, Secchi disk depth, and nitrate and orthophosphate concentration, but lowerthan-average streamflow and water diversion (Fig. 6). These environmental conditions were opposite and significantly different $(P<0.05)$ from those in wet years. Normal years were similar to wet years, but had significantly $(P<0.05)$ higher precipitation as rainfall, specific conductance, orthophosphate concentration and water export, and lower outflow, streamflow, water temperature, wind velocity, and silica concentration. Dry years were similar to critically-dry years, but had significantly $(P<0.05)$ lower Secchi disk depth, wind velocity, and nitrate and orthophosphate concentration and higher water temperature, streamflow, outflow, and water export. Nutrient concentrations differed among water-year types, but daily values were rarely limiting. Daily average concentrations were $476.4 \pm 138.8$ (SD) $\mu \mathrm{m} \mathrm{L}^{-1}$ for silica, $25.3 \pm 25.9$ (SD) $\mu \mathrm{m} \mathrm{L}^{-1}$ for nitrate and $2.9 \pm 1.5$ (SD) $\mu \mathrm{m} \mathrm{L}^{-1}$ for orthophosphate and were below detectable limits only 10 times for nitrate and orthophosphate combined in the 19-year record $(n=3,025)$.

These significant differences in environmental conditions among water-year types may have contributed to significant differences in phytoplankton group biovolume among wateryear types, because maximum biovolume in wet or normal years was usually accompanied by minimum biovolume in dry or critically-dry years and the reverse (Fig. 7). Diatom, green, bluegreen, and chrysophyte biovolume was higher $(P$ $<0.05$ ) in normal and wet years than dry or critically-dry years. This contrasted with cryptophytes, green flagellates, and miscellaneous flagellate biovolume that was higher $(P$ $<0.05)$ in dry and critically-dry years than wet or normal years. However, the above average biovolume of green flagellates in wet and dry years or miscellaneous flagellates in wet and critical years, was not statistically different and may be due to the different response of species within these groups.

Among the diatoms, pennate and centric diatom biovolume was significantly higher than average $(P<0.05)$ in either normal or wet years (Fig. 8). However, both pennate and centric diatom biovolume, were lower than average and did not differ significantly between dry and critically-dry years.

Climate-related environmental variation and phytoplankton community biovolume-PCA identified four unique combinations of environmental conditions (axes) that accounted for $75 \%$ of the climatically related environmental variation among water-year types. In general, these axes described wet-cool (axis 1), wet-warm (axis 2), dry-cool (average temperature), (axis 3) and dry-warm (axis 4) conditions (Table 1), but the suite of variables and their relative importance differed for each axis. The combination of high positive axis coefficients for outflow and the $\mathrm{Si}: \mathrm{P}$ ratio, and high negative axis coefficients for specific conductance and water export, suggested axis 1 and 2 described wet conditions. However, axis 1 described higher outflow and specific conductance, and lower Secchi disk depth, water temperature, wind velocity, water export, and silica concentration than axis 2 . 

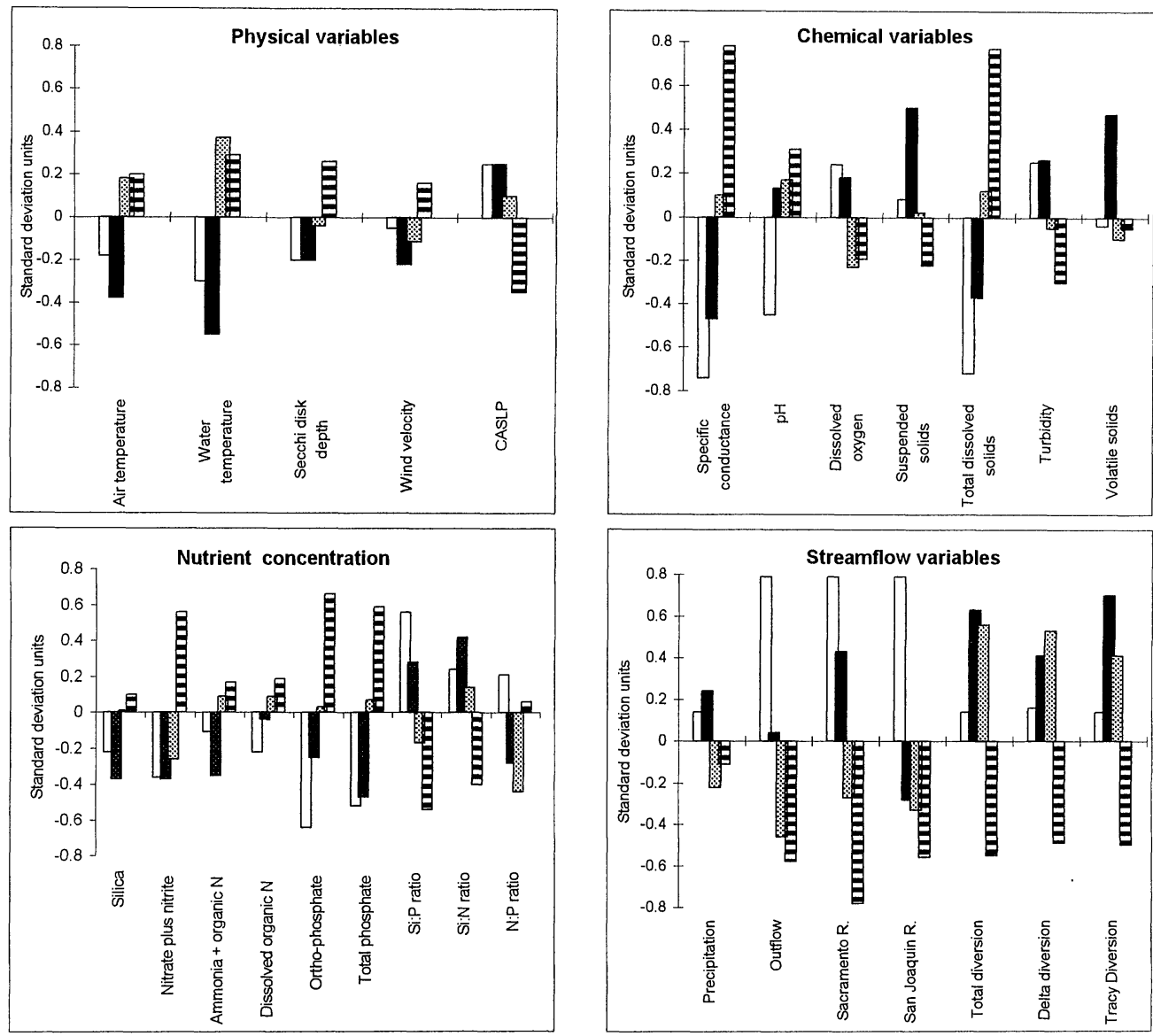

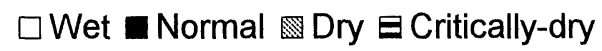

Fig. 6. Average SD units for physical and chemical variables among water-year types.

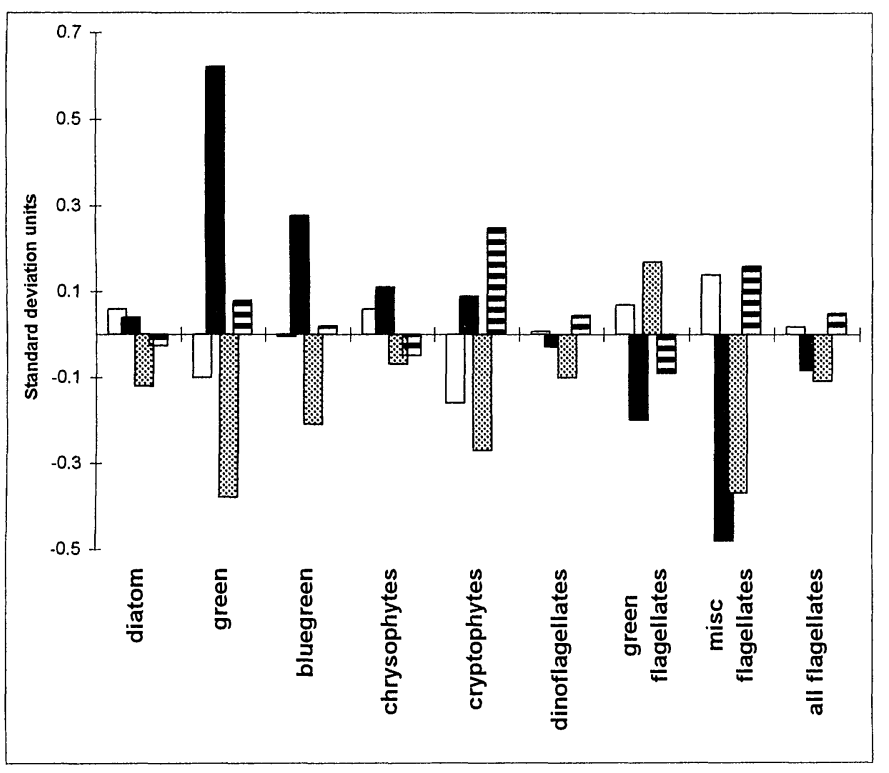

$\square$ wet $\mathbf{a}$ normal 图dry $\Xi$ critically-dry

Fig. 7. Average SD units for phytoplankton species group biovolume among water-year types.
That axis 3 and 4 described relatively dry conditions was suggested by negative axis coefficients for outflow, and positive axis coefficients for Secchi disk depth and specific conductance. However, axis 4 described warmer, more turbid, and less windy conditions with a higher $\mathrm{Si}: \mathrm{N}$ ratio than axis 3 .

Phytoplankton species group biovolume was significantly correlated with the climatically related environmental variation among water-year types described by these four principal component axes. Positive correlation with wet-cool axis 1 and negative correlation with dry axes 3 and 4, suggested pennate diatom, green, and bluegreen algal biovolume was high in wetter years (Table 2). Centric diatom biovolume was not correlated with the wet conditions described by axes 1 and 2 , but was negatively correlated with the dry conditions described by axis 3 . In contrast, negative correlation with axis 1 and positive correlation with axis 4 suggested that the green flagellate and miscellaneous flagellate species group biovolume was low in wet and cool years and high in dry and warm years.

Significant correlation between selected diatom species and climatically related environmental axes supported the potential influence of wet and dry climatic conditions on the partitioning of biovolume among diatoms. The chain-form- 


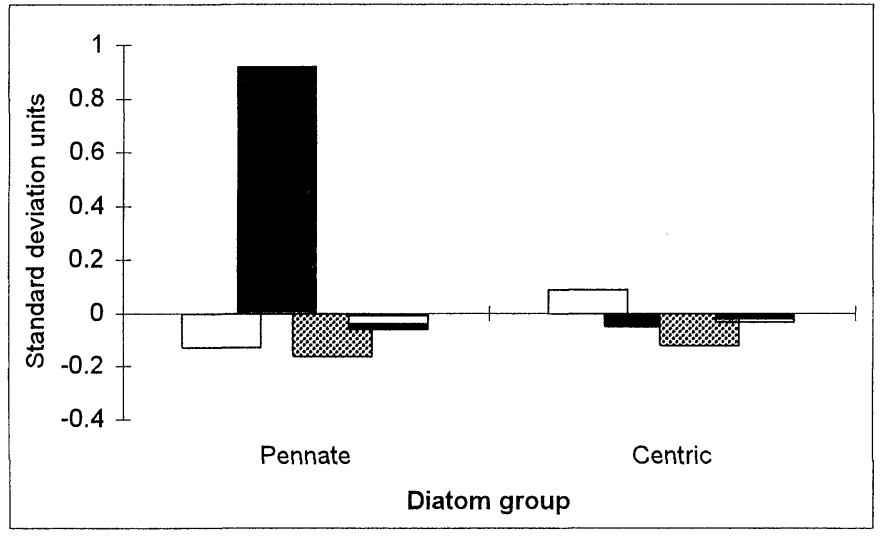

$\square$ Wet $\square$ Normal Dry $\boxminus$ Critically-dry

Fig. 8. Average SD units for pennate and centric diatom biovolume among water-year types.

ing centric diatoms, Aulacoseira granulata and Skeletonema potamos were negatively correlated with wet-cool axis 1 (Table 3). These species commonly occur in the southern Delta during the summer, when salinity is high from discharge of agricultural return water and the seasonal peak in water temperature is increased by long residence time. In contrast, single-celled centric diatoms (e.g., Cyclotella spp.) and pennate diatoms (e.g., Asterionella formosa and Nitzschia spp.) that commonly occur in cool, freshwater regions upstream were positively correlated with wet-cool axis 1 .

Associations between phytoplankton biovolume and individual environmental variables-Associations suggested by correlation between climatically related environmental axes and centric and pennate diatom biovolume were examined further by correlation analyses (Pearson correlation coefficients) with individual environmental variables. Pennate diatom biovolume among stations was negatively correlated with water temperature $(r=-0.57 ; P<0.01)$, specific conductance $(r=-0.32 ; P<0.05)$ and Secchi disk depth $(r$

Table 1. Principal component axes describing climatically-related environmental variation between 1975 and 1993. Comparatively high axis coefficients are in bold type. $N=60$.

\begin{tabular}{lrrrr}
\hline \hline & \multicolumn{4}{c}{ Principal component axes } \\
\cline { 2 - 5 } \multicolumn{1}{c}{ Variable } & Axis 1 & Axis 2 & Axis 3 & Axis 4 \\
\hline Outflow & $\mathbf{0 . 4 3}$ & -0.01 & -0.28 & -0.17 \\
Secchi disk depth & -0.28 & 0.10 & $\mathbf{0 . 4 3}$ & 0.23 \\
Water temperature & -0.22 & 0.29 & 0.09 & $\mathbf{0 . 3 5}$ \\
Specific conductance & -0.25 & $-\mathbf{0 . 4 1}$ & 0.10 & 0.03 \\
Wind velocity & -0.14 & 0.02 & $\mathbf{0 . 5 2}$ & $-\mathbf{0 . 4 2}$ \\
Agricultural diversion & $\mathbf{- 0 . 4 0}$ & -0.07 & -0.15 & 0.23 \\
Dissolved oxygen & 0.28 & 0.07 & $\mathbf{0 . 5 6}$ & 0.14 \\
pH & $\mathbf{0 . 3 7}$ & -0.25 & 0.11 & -0.02 \\
Silica concentration & -0.16 & $\mathbf{0 . 4 7}$ & -0.28 & 0.15 \\
Si:P ratio & $\mathbf{0 . 3 6}$ & $\mathbf{0 . 3 5}$ & 0.11 & 0.18 \\
Si : N ratio & 0.29 & -0.11 & 0.06 & $\mathbf{0 . 6 3}$ \\
N:P ratio & 0.04 & $\mathbf{0 . 5 4}$ & 0.07 & $-\mathbf{0 . 3 1}$ \\
Percent variation & 33 & 18 & 14 & 10 \\
\hline
\end{tabular}

Table 2. Correlation between principal component axes describing climatically-related environmental axes and phytoplankton species group biomass. Correlations are significant at the 0.01 (bold type) and 0.05 (regular type) level. $N=60$.

\begin{tabular}{lcccc}
\hline \hline \multirow{1}{*}{ Group } & \multicolumn{4}{c}{ Environmental axes } \\
\cline { 2 - 5 } & Axis 1 & Axis 2 & Axis 3 & Axis 4 \\
\hline Diatom, all & & & -0.31 & -0.27 \\
$\quad$ Pennate diatom & $\mathbf{0 . 7 6}$ & & -0.27 & $-\mathbf{0 . 3 7}$ \\
$\quad$ Centric diatom & & & -0.29 & \\
Green & $\mathbf{0 . 6 2}$ & -0.26 & $-\mathbf{0 . 3 5}$ & -0.28 \\
Bluegreen & $\mathbf{0 . 5 7}$ & & -0.28 & \\
Cryptophytes & & $-\mathbf{0 . 4 3}$ & & \\
Green flagellates & $\mathbf{- 0 . 4 4}$ & & & $\mathbf{0 . 3 3}$ \\
Miscellaneous flagellates & $-\mathbf{0 . 4 6}$ & -0.27 & & \\
Dinoflagellates & & & & \\
Chrysophytes & & & & \\
\hline
\end{tabular}

$=-0.26 ; P<0.05$ ) (Fig. 9). Centric diatom biovolume was not significantly correlated with individual environmental variables, but a somewhat different response of centric and pennate diatoms to environmental conditions was suggested by the positive correlation between total diatom biovolume and water temperature $(r=0.28 ; P<0.05)$. The negative correlation between pennate diatom biovolume and Secchi disk depth $(r=-0.26 ; P<0.05)$ persisted for total biovolume.

Water diversion was an important anthropogenic factor and significantly reduced the yearly total diatom biovolume in the estuary $(r=-0.78 ; P<0.01)$. The negative correlation was due to the loss of centric $(r=-0.78 ; P<0.01)$ and not pennate $(r=0.07 ; P>0.05)$ diatom biovolume (Fig. 10). A significant positive correlation between total diatom biovolume and both the San Joaquin River inflow ( $P$ $<0.01)$ and the N:Si ratio $(r=-0.68 ; P<0.01)$ also

Table 3. Correlation between principal component axes describing climatically-related environmental variation and individual phytoplankton species biomass. Correlations are significant at the 0.01 (bold type) or at the 0.05 (regular type) level. $N=60$.

\begin{tabular}{|c|c|c|c|c|}
\hline \multirow[b]{2}{*}{ Diatom species } & \multicolumn{4}{|c|}{ Environmental axes } \\
\hline & Axis 1 & Axis 2 & Axis 3 & Axis 4 \\
\hline \multicolumn{5}{|l|}{ Centric diatoms } \\
\hline Aulacoseira granulata & -0.58 & & & \\
\hline Skeletonema potamos & -0.34 & & & \\
\hline Skeletonema costatum & -0.39 & 0.36 & & -0.36 \\
\hline Thalassiosira spp. & & & -0.31 & -0.54 \\
\hline Cyclotella spp. & 0.51 & & -0.31 & -0.26 \\
\hline Stephanodiscus spp. & 0.66 & & -0.34 & \\
\hline \multicolumn{5}{|l|}{ Pennate diatoms } \\
\hline Nitzschia spp. & 0.89 & & & \\
\hline Achnanthes spp. & 0.66 & -0.32 & & \\
\hline Rhoicosphenia spp. & 0.50 & & & \\
\hline Gomphonema spp. & 0.61 & & & \\
\hline Cymbella Spp. & 0.58 & & & \\
\hline Asterionella formosa & 0.57 & & & \\
\hline Fragilaria spp. & 0.42 & & & \\
\hline
\end{tabular}



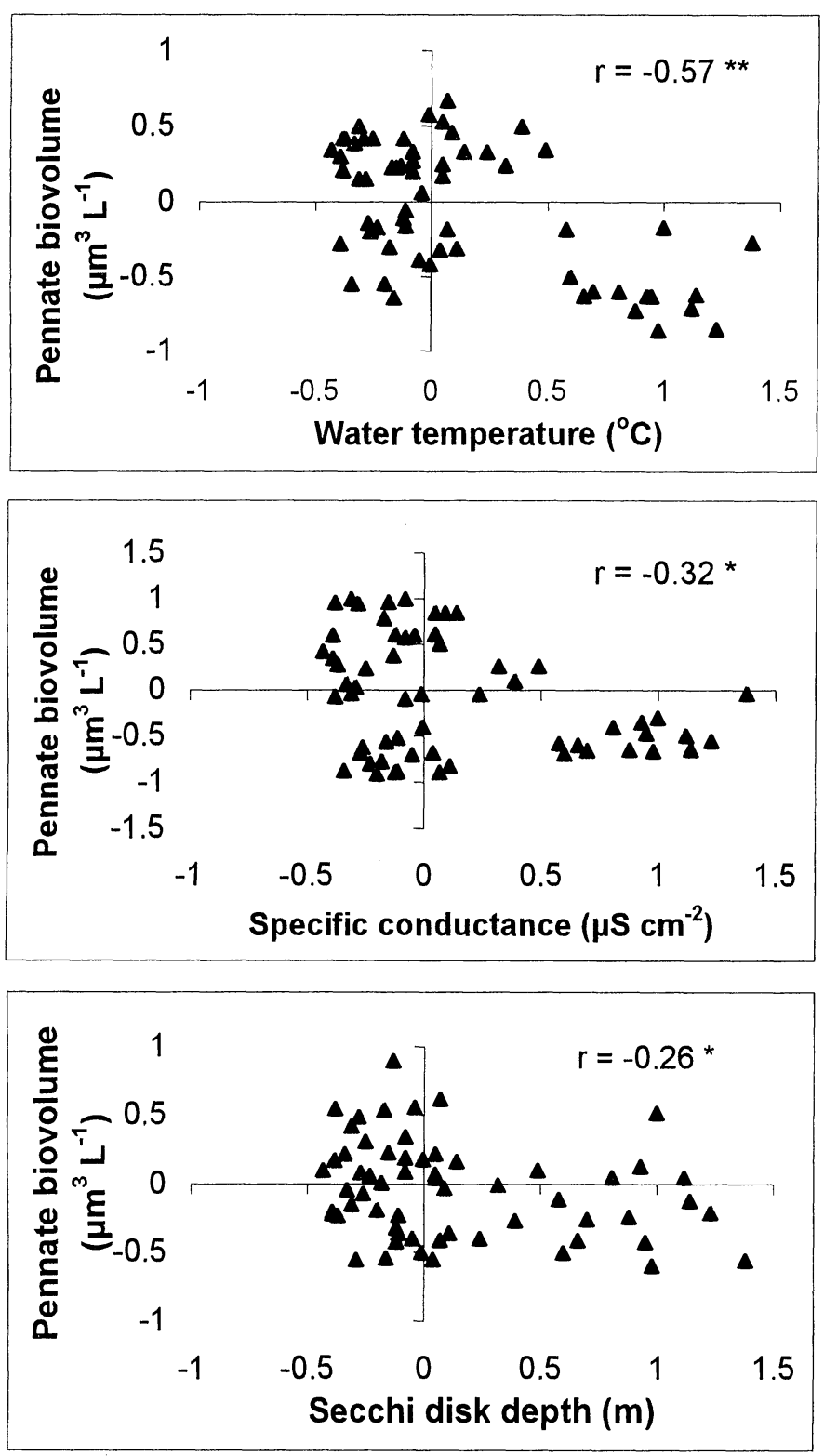

Fig. 9. Correlation between pennate diatom biovolume and selected environmental variables stratified by station and water-year type. Correlation coefficients were significant at the $0.01(* *)$ or 0.05 (*) level. $^{*}$

suggested San Joaquin River diatoms accounted for most of the diatom loss. The N:Si ratio is a good index of the San Joaquin River because nitrate concentrations are at least four times higher in the San Joaquin River than the Sacramento River, the largest river in the estuary (Lehman 1996b). Current time series analyses indicate all of the above correlations were not produced by seasonal autocorrelation (Lehman unpubl.).

\section{Discussion}

Phytoplankton community biovolume and climate-The correlation of phytoplankton species and species group bio-
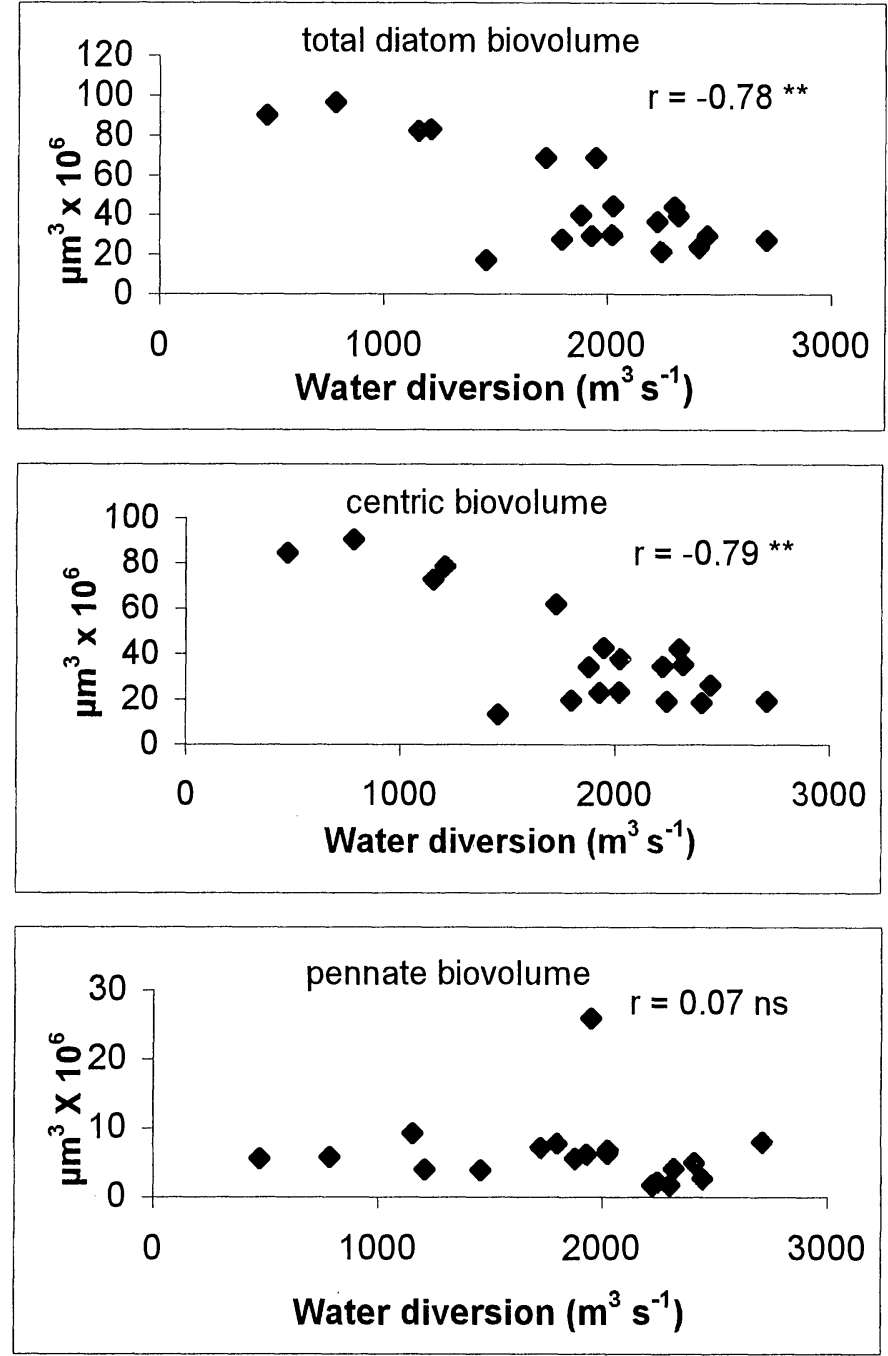

Fig. 10. Correlation between total, centric, and pennate diatom biovolume in the northern estuary and agricultural diversion flow. Correlation coefficients were significant at the $0.01\left(^{* *}\right), 0.05\left(^{*}\right)$ or nonsignificant (ns) level.

volume with climate related environmental variation among water-year types suggested the distribution of biomass within the phytoplankton community was sensitive to interannual variation in precipitation and associated environmental conditions produced by climate. Freshwater pennate and singlecelled centric diatom and green and bluegreen algal biovolume was high in wet years and was replaced by flagellate species and chain-forming centric diatom biovolume in dry and critically-dry years. The shift in phytoplankton species and species group biovolume between wet and dry conditions was supported by previous research with abundance data. Cryptophytes were abundant in the drought year 1977 (Lehman and Smith 1991; Lehman 1996a) and densities increased after the 1977 climate regime shift in the eastern Pacific (Lehman and Smith 1991). In addition, diatoms were most abundant in wet and normal water-year types, while flagellate groups were most abundant in dry and criticallydry water-year types (Lehman 1996a). That these changes could be isolated from a highly managed estuary like SFBE, 
suggested natural variation is an important driving factor for long-term changes in phytoplankton community biomass and therefore a potentially important factor in estuarine production that is dependent on the flow of carbon through the food web.

This study also demonstrated the potential influence of the 1977 climate-induced shift in water-year type on phytoplankton community biovolume. The 1977 climate regime shift and associated El Niño conditions in the eastern Pacific (Trenberth and Hurrell 1994) produced an increase in the frequency of wet and critically-dry water-year types in the SFBE. These water-year types were characterized by very different phytoplankton community biovolume for 19751993. If we assume the associations among phytoplankton community biovolume and climatically-related environmental conditions among water-year types for 1975-1993 were representative of those in previous years of the century, then the 1977 climate shift was an important contributing factor to the shift in phytoplankton community biovolume after 1976. The shift in the phytoplankton community toward fewer diatoms after 1976 was supported by the dominance of diatoms in the 1975-1976 biovolume data of this study, 1975-1976 density data (Lehman and Smith 1991) and 1972-1974 class abundance data (State of California and U.S. Department of Interior 1977).

Controlling mechanisms-Physical and chemical variables associated with streamflow were a major driving force for changes in the phytoplankton community biovolume in response to climate. Climatically-related environmental axes were derived from a climate index that best described wet and dry precipitation patterns in the San Francisco Bay region and accounted for $75 \%$ of the climatically-related variation. Significant and high correlation between these climatically-related environmental axes and phytoplankton species and species group biovolume suggested physical mechanisms were potentially important factors influencing phytoplankton community biovolume. Physical mechanisms have long been credited with changes in natural phytoplankton communities, because the nonequilibrium nature of their environment precludes competition (Hutchinson 1967). This would be particularly true in the highly variable estuarine environment in SFBE.

The low light, turbulent, and low residence time condition produced by high streamflow in wet years was associated with high biovolume of pennate and single-celled centric diatoms. These diatoms are usually abundant in the spring when vertical mixing is high (Reynolds and Reynolds 1985; Harris 1986) and light is low (Makulla and Sommer 1993) or photoperiod is short (Reynolds and Reynolds 1985; Sommer 1994). The pennate diatoms A. formosa, Fragilaria crotonensis, and Tabellaria fenestrata and the centric diatoms Stephanodiscus spp. and Cyclotella spp. grow well in low light environments compared with other diatoms, including A. granulata that tolerate moderate light (Reynolds and Reynolds 1985; Kilham et al. 1986; Makulla and Sommer 1993). Diatoms also have heavy silicate shells that sink out of the water column and require sufficient vertical mixing from high streamflow to keep cells suspended in the water column (Harris 1986). Further, pennate diatoms commonly occur in freshwater lakes and reservoirs and require high streamflow to transport cells downstream (Trimbee and Harris 1983). In this study, the association between pennate diatom biovolume and freshwater transport was supported by the negative correlation between pennate diatom biovolume and specific conductance.

Water temperature was probably another important controlling factor for phytoplankton community biovolume, because it was an important defining variable for the climatically-related environmental axes. Diatoms can be sensitive to water temperature and are generally more common at low water temperature than green and bluegreen algae (Tilman et al. 1986). As in this study, pennate diatoms are often associated with cool water temperatures (Reynolds and Reynolds 1985), and are abundant in cold water conditions at the bottom of the Great Lakes and littoral zone of rivers (Kingston et al. 1983) and beach ponds (Levandowsky 1972). The pennate diatoms, F. crotonensis, Nitzschia spp., and A. formosa, and the single-celled centric diatoms, $C y$ clotella spp. and Stephanodiscus spp. were common during wet and cool conditions in SFBE. These diatoms characterize cool water conditions and commonly occur in temperate waters during the spring when water temperatures are low (Reynolds and Reynolds 1985; Tilman et al. 1981).

In contrast, cryptophyte, green flagellate, and miscellaneous flagellate biovolume was positively associated with the low streamflow and associated high water transparency and water temperature that characterized dry and criticallydry conditions. Flagellates are generally favored by the high residence time, water temperature, light intensity, and long photoperiod associated with dry conditions (Reynolds and Reynolds 1985). In general, Cryptophytes (Reynolds and Reynolds 1985) and flagellates (Levasseur et al. 1984) tolerate high water temperature and were abundant during critical years in SFBE (Lehman 1996a) when average water temperature increased by $2-5 \%$ (Lehman 1996b). Cryptophytes also tolerate high light intensities and long photoperiod (Reynolds and Reynolds 1985) that increased by 1345\% during critically-dry years in SFBE (Lehman 1996b). Their small size makes them less susceptible to sinking in stable waters during dry conditions and their mobility allows them to avoid the high light and temperatures near the surface (Sournia 1982). The stable water column in dry years may also facilitate flagellate movement in the water column by reducing interference and physical damage from turbulence (Harris 1986). Lastly, flagellates are often heterotrophic and increase in stable conditions due to their ability to utilize organic carbon that may accumulate at high residence times (Haffner et al. 1980).

Nutrient concentration often controls phytoplankton species composition (Tilman et al. 1981), but it was probably not important in northern SFBE. Here monthly average nutrient concentrations are above limiting levels in all wateryear types (Peterson et al. 1989; Lehman 1996b). In addition, negative or non-significant cross-correlation between average monthly nutrient and Chl $a$ concentration suggested phytoplankton biomass did not vary in response to nutrient concentration (Lehman 1992). However, the possible influence of excess nutrients on species composition is uncertain, because growth and competition studies are rarely conducted 
above limiting concentrations. Coherence between changes in species composition and nutrient ratios was observed in African (Kilham et al. 1986) and Rocky Mountain (Kilham et al. 1996) lakes when nutrients were in excess. Seemingly excess nutrient concentrations could affect the growth of estuarine species that may have a higher Ks than species in oligotrophic waters or when ambient nutrient concentrations are a poor indicator of uptake kinetics (Brezinski 1992). As a result, it is possible the correlation of pennate diatoms in the Fragilaria family group, A. formosa, T. fenestrata and $F$. crotonensis, and Nitzschia spp., with the high $\mathrm{Si}: \mathrm{P}$ ratio on axis 1 may have some ecological significance. Pennate diatoms in the Fragilaria family commonly occur when the Si:P ratio is high (Kilham et al. 1986; Makulla and Sommer 1993; Kilham et al. 1996).

The preceding discussion focuses on environmental factors or bottom-up control of phytoplankton community biovolume between wet and dry conditions, but top-down control is an equally important factor controlling ecosystem structure (Carpenter et al. 1985). The increase of cryptomonads (Lehman and Smith 1991) in the western region of SFBE during the 1977 drought coincided with an upstream increase in abundance of the estuarine clam Mya arenaria (Nichols 1985). Similarly, establishment of the brackish-water clam Potamocorbula amurensis in the western region since 1987 coincided with a decrease in diatom density (Lehman $1996 a, b)$ and a factor of 10 decrease in Chl $a$ concentration in the western region (Alpine and Cloern 1992). Information on the influence of clam grazing on upstream phytoplankton communities is limited, but densities of the introduced freshwater clam Corbicula fluminea did not increase after 1980 (Lehman 1996b). Information on the impact of zooplankton herbivory is also limited, but phytoplankton and zooplankton biomass are positively correlated (Lehman 1992). However, similar changes in percentage of phytoplankton community biovolume throughout SFBE, despite local differences in benthic and zooplankton density, suggest regional processes were important to the phytoplankton community between 1975 and 1993 .

Lastly, anthropogenic processes associated with water management were major factors controlling total and centric diatom biovolume, because a large portion of SFBE water is diverted from the southern region of the estuary where the highest Chl $a$ concentrations and densities of chain-forming centric diatoms occur (Lehman 1996b). Previous research demonstrated the potential influence of water diversion on the interannual variation of phytoplankton species composition (Lehman and Smith 1991) and Chl $a$ biomass (Jassby et al. 1996). However, water diversion was not the primary factor controlling percentage of phytoplankton community biovolume throughout the estuary, because similar changes in biovolume percentage occurred at all stations, despite their proximity to the southern region.

\section{Conclusion}

The association between climatically-related environmental variation among water-year types and the distribution of biovolume within the phytoplankton community demonstrat- ed the link between long-term, large-scale global climate change processes and regional estuarine phytoplankton production. This link was apparent even though the estuary was highly impacted by anthropogenic processes. The highly structured and predictable nature of long-term changes in phytoplankton community biovolume became apparent once the data was organized by water-year type, because wateryear type reflected the nonlinear influence of climate change associated with El Niño on the phytoplankton community in SFBE. Lastly, changes in phytoplankton species biovolume with climate demonstrated the potential link between global climate change and total estuarine production, because the distribution of biovolume within the phytoplankton community directly influences the quantity and quality of carbon available at the base of the food web.

\section{References}

Aebischer, N. J., J. C. Coulson, And J. M. Colebrook. 1990. Parallel long-term trends across 4 marine trophic levels and weather. Nature 347: 753-755.

Alpine, A. E., AND J. E. Cloern. 1992. Trophic interactions and direct physical effects control phytoplankton biomass and production in an estuary. Limnol. Oceanogr. 37: 946-955.

Barber, R. T., AND R. P. Chavez. 1983. Biological consequences of El Niño. Science 222: 1203-1210.

Baughmgartner,T., V. Ferreira-Bartina, H. Shrader, and A. SOUTAR. 1985. A 20-year varve record of siliceous phytoplankton variability in the central gulf of California. Mar. Geol. 64: 113-129.

BennetT W. A., And P. B. Moyle. 1996. Where have all the fisheries gone? Interactive factors producing fish declines in the Sacramento-San Joaquin Estuary, p. 519-542. In J. T. Hollibaugh [ed.], San Francisco Bay: The Ecosystem. Pac. Div. Amer. Assoc. Adv. Sci.

BREZINSKI, M. A. 1992. Cell-cycle effects on kinetics of silicic acid uptake and resource competition among diatoms. J. Plankton Res. 14: 1511-1539.

CDWR, California Department of Water Resources. 1998. California Water Plan Update. Volume I. Bulletin 160-98. Sacramento.

Carpenter, S. R., J. F. Kitchell, And J. R. Hodgson. 1985. Cascading trophic interactions and lake productivity. BioSci. 35: $634-639$.

Cloern, J. E., And R. T. Cheng. 1981. Simulation model of Skeletonema costatum population dynamics in northern San Francisco Bay, California. Estuar. Coast. Shelf Sci. 12: 83-100.

Colebrook, J. M. 1986. Environmental influences on long-term variability in marine plankton. Hydrobiol. 142: 309-325.

Conley, D. S., AND T. C. Malone. 1992. Annual cycle of dissolved silicate in Chesapeake Bay; implications for the production of phytoplankton biomass. Mar. Ecol. Prog. Ser. 81: 121-128.

DiCKSON, R. R., AND P. C. REID. 1983. Local effects of wind speed and direction on the phytoplankton of the Southern Bight. J. Plankton Res. 5: 441-454.

Frenette, J-J., W. F. Vincent, J. J. Dodson, and C. Lovejoy. 1995. Size-dependent variations in phytoplankton and protozoan community structure across the St. Lawrence transition region. Mar. Ecol. Prog. Ser. 120: 99-110.

Goldman, C. R., A. D. JASSBY, AND T. POwEll. 1989. Interannual fluctuations in primary production: Meterological forcing at two subalpine lakes. Limnol. Oceanogr. 34: 310-323.

Haffner, G. D., G. P. Harris, AND M. K. Jarai. 1980. Physical variability and phytoplankton communities III. Vertical struc- 
ture in phytoplankton populations. Arch. Hydrobiol. 89: 363381.

HARris, G. P. 1986. Phytoplankton ecology. Chapman and Hall.

Hutchinson, G. E. 1967. A Treatise on limnology, Vol. II. Wiley.

Jassby, A. D., J. R. KosefF, And S. G. Monismith. 1996. Processes underlying phytoplankton variability in San Francisco Bay, p. 325-350. In J. T. Hollibaugh [ed.], San Francisco Bay: The ecosystem. Pac. Div. Amer. Assoc. Adv. Sci.

Kilham, P., S. S. Kilham, and R. E. Hecky. 1986. Hypothesized resource relationships among African planktonic diatoms. Limnol. Oceanogr. 31: 1169-1181.

Kilham, S. S., E. C. Theriot, And S. C. Fritz. 1996. Linking planktonic diatoms and climate change in the large lakes of the Yellowstone ecosystem using resource theory. Limnol. Oceanogr. 41: 1052-1062.

Kingston, J. C., R. L. Lowe, E. F. Stoermer, And T. B. LAdewski. 1983. Spatial and temporal distribution of benthic diatoms in northern Lake Michigan. Ecology 64: 1566-1580.

Lange, C. B., S. K. Burke, And W. H. Berger. 1990. Biological production off southern California is linked to climatic change. Clim. Chang. 16: 319-329.

LEHMAN, P. W. 1992. Environmental factors associated with longterm changes in chlorophyll concentration in the SacramentoSan Joaquin Delta and Suisun Bay, California. Estuaries 15: 335-348.

-1996a. Changes in Chl $a$ concentration and phytoplankton community composition with water-year type in the upper San Francisco Bay Estuary, p. 351-374. In J. T. Hollibaugh [ed.], San Francisco Bay: The ecosystem. Pac. Div. Amer. Assoc. Adv. Sci.

- 1996b. Water quality conditions in the Sacramento-San Joaquin Delta, 1970-1993. Environmental Services Office, California Department of Water Resources, Sacramento.

- AND R. W. SMITH. 1991. Environmental factors associated with phytoplankton succession for the Sacramento-San Joaquin Delta and Suisun Bay Estuary, California. Estuar. Coast. Shelf. Sci. 32: 105-128.

LEVANDOWSKY, M. 1972. An ordination of phytoplankton populations in ponds of varying salinity and temperature. Ecology 53: 398-407.

Levasseur, M., J.-C. Therriault, And L. Legendre. 1984. Hierarchical control of phytoplankton succession by physical factors. Mar. Ecol. Prog. Ser. 19: 211-222.

Makulla, A., AND U. SOMmER. 1993. Relationships between resource ratios and phytoplankton species composition during spring in five north German lakes. Limnol. Oceanogr. 38: 846856.

Mallin, M. A. 1994. Phytoplankton ecology of North Carolina estuaries. Estuaries 17: 561-574.

Malone, T, L. H. Crocker, S. E. Pike, And B. W. Wendler. 1988. Influences of river flow in the dynamics of phytoplankton production in a partially stratified estuary. Mar. Ecol. Prog. Ser. 48: 235-249.

Muller-NavarRA, D., AND W. LAMPERT. 1996. Seasonal patterns of food limitation in Daphnia galeata: Separating food quantity and food quality effects. J. Plankton Res. 18: 1137-1157.

NiCHOLS, F. H. 1985. Increased benthic grazing: An alternative explanation for low phytoplankton biomass in northern San Fran- cisco Bay during the 1976-1977 drought. Estuar. Coast. Shelf Sci. 21: 379-388.

Peterson, D. H., D. R. Cayan, J. F. Festa, F. H. Nichols, R. A. Walters, J. V. Slack, S. E. Hager, and L. E. Schemel. 1989. Climate variability in an estuary: Effects of river flow on San Francisco Bay, p. 419-442. In D. H. Peterson, [ed.], Aspects of climate variability in the Pacific and Western Americas. Geophys. Monogr. 55. Amer. Geophys. Union.

Reynolds, C. S., AND J. B. REynOLDS. 1985. The atypical seasonality of phytoplankton in Crose Mere, 1972: An independent test of the hypothesis that variability in the physical environment regulates community dynamics and structure. Br. Phycol. J. 20: 227-242.

Sherwood, C. R., D. A. Jay, R. B. Harvey, P. Hamilton, and C. A. Simenstad. 1990. Historical changes in the Columbia River Estuary. Prog. Oceanogr. 25: 299-352.

SOMMER, U. 1994. The impact of light intensity and daylength on silicate and nitrate competition among marine phytoplankton. Limnol. Oceanogr. 39: 1680-1688.

SourniA, A. 1982. Form and function in marine phytoplankton. Biol. Rev. 57: 347-394.

State of California, and U.S. Department of the InTerior. 1977. Delta-Suisun Bay ecological studies. Biological methods and data for 1968-1974. Sacramento.

STRATHMANN, R. R. 1967. Estimating the organic carbon content of phytoplankton from cell volume or plasma volume. Limnol. Oceanogr. 12: 411-418.

Strub, P. T., T. Powell, and C. R. Goldman. 1985. Climate forcing: Effects of El Niño on a small, temperate lake. Science 227: $55-57$.

Therriault, J.-C., And M. Levasseur. 1985. Control of phytoplankton production in the lower St. Lawrence Estuary: Light and freshwater runoff. Rev. Ecol. Syst. 112: 77-96.

Tilman, D., M. MatTson, And S. Langer. 1981. Competition and nutrient kinetics along a temperature gradient: An experimental test of a mechanistic approach to niche theory. Limnol. Oceanogr. 26: 1020-1033.

, R. Kiesling, R. Sterner, S. S. Kilham, and F. A. JohnSON. 1986. Green, bluegreen and diatom algae. Taxonomic differences in competitive ability for phosphorous, silicon and nitrogen. Arch. Hydrobiol. 106: 473-485.

TonT, S. A. 1989. Climatic change: Response of diatoms and dinoflagellates, p. 161-163. In D. H. Peterson [ed.], Aspects of climate variability in the Pacific and Western Americas. Geophys. Monogr. 55. Amer. Geophys. Union.

Trenberth, K. E., AND J. W. HurRell. 1994. Decadal atmosphereocean variations in the Pacific. Clim. Dyn. 9: 303-319.

TrimbeE, A. M., AND G. P. HARRIS. 1983. Use of time-series analysis to demonstrate advection rates of different variables in a small lake. J. Plankton Res. 5: 819-833

Tyler, M. A., AND H. H. Seliger. 1981. Selection for a red tide organism: Physiological responses to the physical environment. Limnol. Oceanogr. 26: 310-324.

U.S. Environmental Protection Agency (US EPA). 1983. Methods for chemical analysis of water and wastes. Technical Report EPA-600/4-79-020.

Received: 18 June 1999

Accepted: 25 November 1999 Amended: 10 January 2000 